\title{
We Must Take These Risks Interview with Matthias Warstat
}

\author{
Radka Kunderová
}

\begin{abstract}
Matthias Warstat (matthias.warstat@fu-berlin.de) is Professor at the Institut für Theaterwissenschaft at the Freie Universität Berlin, and co-director of the Research Centre Interweaving Performance Cultures in Berlin. His research interests have been focused on theatre and society, the theatricality of politics, performance and rituality, or theories of aesthetics. His monographs include Soziale Theatralität. Die Inszenierung der Gesellschaft [Social Theatricality. The Staging of the Society] (2018), Krise und Heilung. Wirkungsästhetiken des Theaters [Crisis and Healing: Aesthetics of Impact in the Theatre] (2005), and Theatrale Gemeinschaften. Zur Festkultur der Arbeiterbewegung 1918-33 [Theatrical Communities: on the Festival Culture of the WorkingClass Movement 1918-33] (2005). He co-authored Theater als Intervention. Politiken ästhetischer Praxis [Theatre as Intervention: The Politics of Aesthetic Praxis] (2015) and Theaterhistoriografie. Eine Einführung [Theatre Historiography: An Introduction] (2012). He ran the ERC project The Aesthetics of Applied Theatre (2012-2017), and the project Theater und Fest in Europa. Zur Inszenierung von Identität und Gemeinschaft [Theatre and Festival in Europe: on the Staging of Identity and Community] (2006-2009). Currently, he leads a sub-project on post-migrant theatre within the Collaborative Research Center 1171 Affective Societies: Dynamics of Social Coexistence in Mobile Worlds. He graduated in modern history and theatre studies at the Freie Universität Berlin, where he received his PhD (2002) and associate professorship (2007). Between 2009 and 2011, he was the spokesman of the Department für Medienwissenschaften und Kunstgeschichte at the Friedrich-Alexander-Universität Erlangen-Nürnberg.
\end{abstract}

[RK] You have been leading a team within the research project Affective Societies, which represents a unique structure of collaboration of scholars from ten disciplines in the humanities and social sciences, developed at the Freie Universität Berlin. Your team's research Emotion and Relationality in Forms of (Post-)Migrant Theater compares (post)-migrant theatres in Berlin and London and thus analyses very contemporary phenomena. Which advantages or, potentially, disadvantages of researching on-going phenomena do you see?

[MW] I believe it to be important that theatre studies express their view on the most urgent contemporary questions of the theatre. Of course, it brings with it some uncertainties when you write about developments that are still going on. But I think we must take these risks if we do not want to limit our discipline to theatre historiography. At 


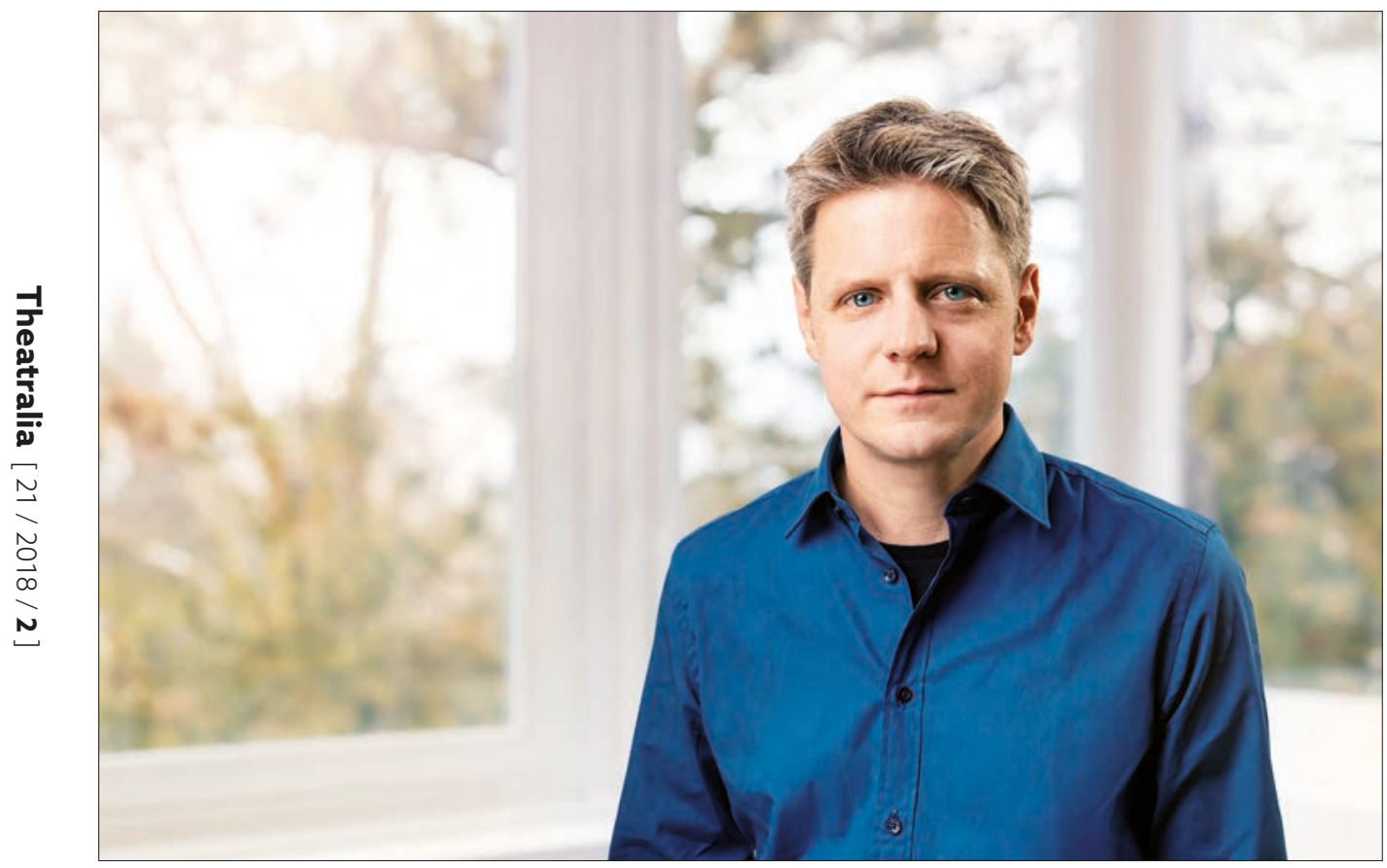

Matthias Warstat. (c) Christina Stivali for IRC, Interweaving Performance Cultures'.

our institute, I observe that the majority of students are primarily interested in contemporary theatre. It would be careless not to respond to this interest. The most current questions, including, for example, those on theatre and migration, are closely linked to historical developments anyway.

[RK] What are the currently dominant theoretical approaches in German-speaking theatre studies? And what perspectives and methodologies should be emphasized or developed in the future, say, ten years, in your opinion?

[MW] In the nineties, the so-called 'performative turn' was perceived and further developed in many ways. There was also an intense interest in new phenomenological methods of performance analysis. These theoretically very demanding projects are now well advanced, so that the discipline is currently in search of new theoretical inspirations. Questions of interculturality and globalization have become very important. As a result of the boom that is currently being experienced in new forms of political theatre, the question of 'the political' is also very urgent in today's theoretical debates.

[RK] In your book Theatrale Gemeinschaften. Zur Festkultur der Arbeiterbewegung 1918-33 (Tübingen und Basel: A. Francke, 2005), you were analysing theatrical aspects of working class celebrations. Studies in performativity beyond theatre seem to represent one of the significant trends of German-speaking theatre studies in recent decades. Is it possible to estimate 
a proportion between current German-speaking scholarship interested in theatre - in the traditional sense of the word - and in performativity of other phenomena of social life?

[MW] Difficult to say. On the one hand, it is nowadays very normal for theatre scholars to also deal with theatrical phenomena outside theatre, for example with the staging of politics. On the other hand, I also observe a kind of return to 'the theatre' in a traditional sense. Perhaps certain disappointments also play a role here: Not all studies on the theatricality of politics, popular culture, fashion or everyday life have turned out to be really fruitful. If it is only a matter of proving once again the overarching theatrical character of the area in question, the gain in knowledge remains small.

[RK] To what extent is it common in German-speaking theatre studies that researchers analyse the theatricality of - an often mediatized - politics? Do you agree with Joachim Fiebach ${ }^{1}$ who considers such a critical analysis one of the key tasks for current theatre scholars?

[MW] We should definitely work on this important field, and Fiebach himself has shown how to reflect critically on mediatised politics with categories of the theatre. We just have to be aware that there are many other disciplines working on these topics, some of them with impressive expertise: The dialogue with political scientists, media scholars, historians, sociologists and others seems to me to be very important, just to ensure that we as theatre scholars do not work on answers that other disciplines have already given.

[RK] How do you perceive a current relationship between German-speaking and Anglophone theatre studies discourses, in case it is even possible do speak of such generalised categories? In your recent study (WARSTAT 2017: 15-29) on current changes in conceptualising the body in the field of theatre studies, you touch upon the differences in research perspectives of Anglophone and German-speaking theoretical discourses during the past decades, how about the present state? In what manner are they co-related and to what extent do they share interests and methodologies?

[MW] One difference has been particularly striking to me in recent years: Many British and American colleagues are at the same time theatre practitioners, meaning they also teach directing, dramaturgy and sometimes even acting. In the research field of applied theatre, which I have worked on recently, almost all researchers in the Anglophone world are also practitioners at the same time. In Germany, this is still rather unusual: Theatre scholars see themselves as historians, theorists or analysts of the theatre, whereas the practical training takes place outside universities. I suspect that in this regard, the German situation is more similar to the Czech one and to the situation in most other continental European countries.

[RK] To publish in German, or to publish in English - is it one of the current dilemmas a German-speaking theatre scholar deals with?

[MW] There is certainly a tendency to publish more and more in English in order to

1 See, for instance, (FIEBACH 2007 or FIEBACH in KUNDEROVÁ 2010: 57-61, 109). 
reach an international audience. At the same time, many German-speaking colleagues feel that we are used to German as a working language and that most of us can write and think better in German than in English. Personally, I believe it would be by far the best solution if many more academic works were translated between the diverse European languages. A reasonable amount of science funding (in particular for the humanities) within the EU could consist in investing much more money in professional translations.

[RK] Being a co-director of the International Research Center Interweaving Performance Cultures, you have been continuously acquainted with the on-going researches of top-rank theatre academics from around the world. What international theoretical approaches do you find most inspiring and do you see, on the contrary, some clichés or blind alleys present in current thinking on theatre?

[MW] In the International Research Centre, it became particularly obvious to me that a theatre history on a really global scale, which would thoroughly reconstruct the transfers and networks of earlier centuries, is still missing. There is still much conceptual work to be done in this field, because in the long run it will not be enough simply to add regional theatre histories, or to compare singular case studies. I also have the impression that good old theatre semiotics is again extremely important for many very contemporary issues such as transcultural theatre, or multilingualism in the theatre. So, it might be worthwhile rereading the major works of theatre semiotics from the eighties and the basic texts of Prague Structuralism and to think further from there on.

[RK] Your experience in directing theatre studies departments - at the Friedrich-AlexanderUniversität Erlangen-Nürnberg and at the Freie Universität Berlin - has provided you with an insight into the political dimension of current academia including its relationships to the (superior) state institutions. In your opinion, is it currently possible to speak of some common political orientation of German-speaking theatre studies - on the level of institutional practice as well as on a discursive level? And if so, is it possible to situate them towards the traditional left-wing/right-wing scale of political thought, or are these categories no longer of use?

[MW] Just as conflicts of identity politics are becoming increasingly relevant in the theatres, so too are theatre studies at university confronting these questions more than before. The most concrete political discussions we had in our institute at Freie Universität Berlin, also with the students, had to do with identity politics in the broadest sense: Is our curriculum sufficiently diverse? Are theatres and universities capable of responding to the social and cultural diversity of the present? Should topics and discourses be actively reoriented towards diversification? Such questions can often not easily be discussed in traditional categories of left and right.

[RK] Recently, you have published a monograph Soziale Theatralität. Die Inszenierung der Gesellschaft (WARSTAT 2018). What key-issues do you find in this area of 'social theatricality'?

[MW] The basic idea of the book is that there is still something like 'society'. Not all philosophers and sociologists would share this view, many of them believe that society 
has almost dissolved in our highly mobile and digital times. In my view, however, there is still society: It is nothing abstract, but something to be experienced day by day in very concrete images and scenes. Such scenes in which we perceive society interest me: scenes of social inequality, as we can experience them in every subway station or shopping centre. How are such scenes constructed? Who are their protagonists? I try to find a terminology for this kind of analysis.

\section{Bibliography}

FIEBACH, Joachim. 2007. Inszenierte Wirklichkeit: Kapitel einer Kulturgeschichte des Theatralen [Staged Reality: a Chapter of the Cultural History of the Theatrical]. Berlin: Theater der Zeit, 2007.

FIEBACH, Joachim. 2010. Předvádění skutečnosti jako její performativní provádění (Performing Reality) [Performing Reality as Performing Reality]. In Radka Kunderová (ed.). Tendence v současném myšleni o divadle [Trends in Contemporary Thinking about Theatre]. Brno: JAMU, 2010: 57-61, 109.

WARSTAT, Matthias. 2017. Kategorienwechsel. Zur jüngeren Kritik an theaterwissenschaftlichen Körperkonzepten [Category Change: on Recent Criticism of Theatre-Scientific Body Concepts]. In Friedemann Kreuder and Ellen Koban and Hanna Voss (eds.). Re/produktionsmaschine Kunst. Kategorisierungen des Körpers in den Darstellenden Künsten [Re/production-machine Art: Categorizations of the Body in the Performing Arts]. Bielefeld: Transcript, 2017: 15-29.

WARSTAT, Matthias. 2018. Soziale Theatralität. Die Inszenierung der Gesellschaft. Paderborn: Wilhelm Fink, 2018. 